\title{
Recenzja Metody terapii logopedycznej. Red. Aneta Domagała, Urszula Mirecka. Lublin, Wydawnictwo Uniwersytetu Marie Curie-Skłodowskiej, 2018, 1094 stron
}

Redaktorki monografii, Aneta Domagała oraz Urszula Mirecka, zaprosiły do współpracy niemal 60 autorów, którzy zgodnie z koncepcją tomu zaprezentowali podejście zarówno teoretyczne, jak i praktyczne. Z tytułową tematyką ściśle wiążą się zagadnienia programowania postępowania terapeutycznego oraz jego realizacji w przypadku poszczególnych jednostek zaburzeń mowy. Książka jest skierowana głównie do logopedów i osób w toku studiów logopedycznych, choć ze względu na poruszaną problematykę oddziaływań wielospecjalistycznych znajdzie swoich odbiorców również wśród pedagogów, psychologów, fizjoterapeutów, ortodontów oraz terapeutów integracji sensorycznej. Praca rozpoczyna się wprowadzeniem, w którym redaktorki w sposób syntetyczny prezentują zawartość poszczególnych rozdziałów, dzięki czemu czytelnik poznaje zamysł umiejscowienia ich w pracy w określonej kolejności.

Część I, zatytułowana Terapia logopedyczna. Opis metod, dotyczy trzech głównych zagadnień i są to: Kompetencja językowa, komunikacyjna i poznawcza kształtowanie i odbudowa, Sprawności realizacyjne - kształtowanie i odbudowa oraz Metody wspomagajace w terapii logopedycznej. Zaprezentowano w niej podstawy teoretyczne wybranych metod, by na dalszych kartach tomu ukazać ich praktyczne zastosowanie w różnych zaburzeniach mowy. Część II: Oddziaływanie terapeutyczne w patologii mowy. Egzemplifikacja stanowi dopełnienie rozważań teoretycznych i jest poświęcona opisowi poszczególnych przypadków pacjentów oraz realizacji procesu terapeutycznego (Postępowanie terapeutyczne. Opis przypadków). Monografię zamykają przykłady działań wielospecjalistycznych, które wspierają terapię logopedyczną (Logopeda $w$ interdyscyplinarnym zespole terapeutycznym). Wartościowe dla czytelnika jest to, że treści dwu części z sobą korespondują, stanowiąc spójne opracowanie dostarczające wiedzy zarazem teoretycznej i praktycznej. 
Autorki pierwszego rozdziału, Kazimiera Krakowiak i Barbara Ostapiuk, przybliżyły metodę fonogestowej wizualizacji głosek. Wskazały w nim między innymi na rolę wzroku w udostępnianiu języka osobom niesłyszącym, opisały technikę mówienia $\mathrm{z}$ fonogestami oraz korzyści płynące z jej zastosowania. Z kolei Anita Lorenc i Agnieszka Dziedzic skupiły się na metodzie werbo-tonalnej, przedstawiając program diagnostyczny, terapeutyczny oraz zastosowanie w praktyce logopedycznej. W następnym rozdziale Ewa Muzyka-Furtak poruszyła zagadnienie ćwiczeń słowotwórczych dla osób z niedosłuchem. Czytelnik może wykorzystać podane przez autorkę propozycje ćwiczeń rozwijających kompetencje leksykalną i gramatyczną z wyszczególnieniem celu, potrzebnych materiałów oraz sposobu wykonania zadań. W rozdziale autorstwa Jagody Cieszyńskiej i Marty Korendo odbiorca tekstu odnajduje wyczerpujące informacje na temat metody krakowskiej: poznaje założenia i cele metody oraz zasady jej stosowania. Opóźniony rozwój mowy stał się tematem tekstu Ewy Hrycyny, w którym krok po kroku została opisana metoda rozwijania słownictwa u dzieci w wieku przedszkolnym. Z kolei Mirosław Michalik i Ewa Przebinda zaprezentowali szczegółowo system alternatywnych i wspomagających sposobów komunikacji (AAC) w zastosowaniu w przypadku osób dotkniętych między innymi autyzmem lub anartrią w mózgowym porażeniu dziecięcym. Temat metod behawioralnych w terapii osób z autyzmem poruszył Wojciech Lipski, który przedstawił dwa podejścia terapeutyczne - metodę wyodrębnionych prób oraz uczenie sytuacyjne. Dla czytelników chcących pogłębić wiedzę z zakresu mutyzmu dużą wartość stanowić będzie opracowanie Zbigniewa Tarkowskiego. Przypomniano w nim kryteria diagnostyczne mutyzmu wybiórczego oraz przedstawiono metodę systemowej analizy i modyfikacji zachowania (SAMZ). Opis opieki terapeutycznej nad pacjentem z padaczką znaleźć można w rozdziale autorstwa Haliny Pawłowskiej-Jaroń. Z kolei Urszula Ciszewska-Psujek przybliżyła metody i techniki glottodydaktyczne. Dzięki temu rozdziałowi logopedzi poznają możliwość zastosowania ich w przypadku dzieci nie tylko dwujęzycznych, ale także jednojęzycznych z zaburzeniami kompetencji gramatycznej. Katarzyna Kaczorowska-Bray i Kamila Talańska poświęciły uwagę osobom dorosłym z głębszą niepełnosprawnością intelektualną, by pokazać funkcjonujące sposoby i style komunikowania się z takimi osobami oraz zaproponować model niedyrektywny. Problematykę anomii, jej podłoża oraz metod pracy w tym zaburzeniu poruszyła Małgorzata Rutkiewicz-Hanczewska. Tekst wzbogacony jest o rysunki, które podsumowują i dopełniają przekazywane w opracowaniu treści. Justyna Żulewska i Karolina Pożoga to autorki kolejnego rozdziału, w którym opisały metody terapii afazji globalnej w różnych ujęciach. Na uwagę zasługuje bogata bibliografia obejmująca prace rodzimych badaczy i publikacje anglojęzyczne. Zagadnienia dotyczące kompetencji językowej, komunikacyjnej i poznawczej (15 rozdziałów) zamyka tekst Anety Domagały, poświęcony prezentacji autorskiej formy oddziaływań 
w chorobie Alzheimera (formuła WSPIERAM). Cenna są podane informacje dotyczące terapii pośredniej w postępowaniu logopedycznym, jak również opracowane szczegółowo wskazania dla opiekunów.

Rozdział Anny Sołtys-Chmielowicz otwiera drugą partię recenzowanej I części, zawierającą rozważania nad kształtowaniem i odbudową sprawności realizacyjnych (11 rozdziałów). Autorka dokonała przeglądu metod mechanicznych i fonetycznych w terapii zaburzeń artykulacji. Danuta Pluta-Wojciechowska uzupełniła polską literaturę o autorską siedmioetapową koncepcję SMURF, która znajduje swoje zastosowanie w usprawnianiu realizacji fonemów w dyslalii obwodowej. Małgorzata Waryszak ukazała zalety stosowania programów akustycznych (PRAAT i WaveSufer) w terapii logopedycznej osób dorosłych, co stanowi interesującą perspektywę dla praktyków nie korzystających dotąd z metod obrazów akustycznych. Metody terapii dzieci z wadą rozszczepową zostały uporządkowane przez Danutę Plutę-Wojciechowską. Opierając się na koncepcji SMURF, autorka wyczerpująco opisała pomoc w przypadku dyslalii i alalii rozszczepowej. Kolejny rozdział Danuty Pluty-Wojciechowskiej przedstawia fizjologiczną terapię miofunkcjonalną w przypadku zaburzeń oddychania i fazy ustnej połykania. Ewelina Abramowicz-Pakuła wskazała na zastosowanie metody elektrostymulacji nerwowo-mięśniowej w pracy z pacjentami z zaburzeniami połykania. Stanowi to interesujące uzupełnienie znanych dotychczas metod terapii dysfagii. W rozdziale na temat terapii osób z dyzartrią Olga Jauer-Niworowska opisała metodę psychologiczno-motoryczną oraz tę, która uwzględnia patomechanizm zaburzeń. Rysunki opracowane przez autorkę ilustrują patomechanizm zaburzeń zrozumiałości mowy w każdym typie dyzartrii. Problematykę zaburzeń płynności mowy u dzieci poruszyły Katarzyna Węsierska i Aleksandra Boroń. Autorki dokonały przeglądu metod terapii jąkania stosowanych w różnych krajach, co niewątpliwie rozszerza obecną perspektywę pracy terapeutycznej z dziećmi jąkającymi się. Własną metodę kształtowania płynności mowy, opartą na naturalnym rytmie mowy, przedstawił Tomasz Woźniak. Z kolei Zbigniew Tarkowski i Agnieszka Okrasińska zaprezentowali systemową terapię jąkania, jej założenia i cele. Tę partię książki kończy rozdział Marty Wysockiej, która dokonała przeglądu metod i programów terapeutycznych usprawniających realizację prozodii.

Ostatnie 4 rozdziały I części tomu są poświęcone metodom, które mogą wspomagać terapię logopedyczną. Wśród nich znalazły się: logorytmika, którą opisuje Marta Wysocka, metoda integracji sensorycznej, przedstawiona przez Monikę Romaniec, terapia psychomotoryczna, stanowiąca temat rozdziału autorstwa Magdaleny Kozłowskiej, oraz relaksacja, której znaczenie i techniki opisała Urszula Mirecka.

Część II monografii, składającą się z 18 rozdziałów w dwu partiach, rozpoczyna rozdział opracowany przez Katarzynę Bieńkowską - opis przypadku dziecka $\mathrm{z}$ uszkodzonym narządem słuchu uczestniczącego $\mathrm{w}$ terapii $\mathrm{z}$ wykorzy- 
staniem metody audytywno-werbalnej. Metodę Warnkego na przykładzie terapii 13-letniego chłopca oraz rezultaty pracy w odniesieniu do centralnych zaburzeń przetwarzania słuchowego przedstawiła Anna Kruczyńska. Rozdział Marleny Kurowskiej prezentuje proces wzbogacania słownika oraz opanowywania form gramatycznych u dwojga dzieci z zaburzeniami mowy i języka pochodzenia korowego. Doświadczeniem włączania metody integracji sensorycznej do terapii logopedycznej chłopca z opóźnionym rozwojem mowy podzieliła się na kartach tomu Monika Romaniec. Proces diagnozy i terapii dwujęzycznych bliźniąt jednojajowych opisała Dorota Wiewióra. Z kolei Joanna Trzaskalik przybliżyła proces i efekty pracy u dziewczynki z sygmatyzmem lateralnym. Zastosowanie logorytmiki w terapii dyslalii rozszczepowej ukazały Agnieszka Banaszkiewicz i Anna Walencik-Topiłko. Rozdział dopełniają fotografie. Na zagadnieniu pracy z dzieckiem z rozszczepem podśluzówkowym skoncentrowała się Natalia Siudzińska. Program terapii został zaprezentowany tabelarycznie, dzięki czemu czytelnik otrzymuje przejrzysty przegląd celów programu i przebiegu jego realizacji. Ta sama autorka, Natalia Siudzińska, zamieściła w kolejnym rozdziale opis dwu przypadków dzieci z rozszczepem podniebienia. Doświadczenie pracy z wykorzystaniem metod kinezjopapingu, manualnej terapii neuromięśniowej i elektrostymulacji przedstawiła Monika Kowalska. Postępowanie terapeutyczne dotyczyło pełnoletniej osoby z hipotonią mięśniową $\mathrm{w}$ mózgowym porażeniu dziecięcym. Łukasz Maj poświęcił uwagę budowaniu kompetencji komunikacyjnej, językowej i kulturowej za pomocą systemu PECS w przypadku pacjenta z niepełnosprawnością sprzężoną. Temat terapii niepłynności mówienia u chłopca w wieku 7 lat poruszyli Agnieszka Siwińska i Krzysztof Szamburski, a ich opracowanie stanowi opis postępowania zarówno logopedycznego, jak i psychologicznego. Kolejna z autorek, Anna Siudak, zaprezentowała - z perspektywy praktyka - techniki stymulacji funkcji poznawczych u osób z afazją. Zakończenie tej partii II części tomu stanowi rozdział Bożeny Dudy i Katarzyny Broniec-Siekaniec, których celem było ukazanie innowacyjnych technologii (C-Eye i EEG Biofeedback) w terapii 26-letniego pacjenta $\mathrm{z}$ głębokimi schorzeniami neurologicznymi.

Ostatnia partia monografii - Logopeda w interdyscyplinarnym zespole terapeutycznym - pokazuje przykłady działań wielospecjalistycznych. Marianna Krawiec i Aleksandra Borowicz podjęły zagadnienie procesu skutecznego włączania osób z uszkodzeniami narządu słuchu do wspólnot komunikacyjnych. Przedstawiły historię dwóch dziewczynek jako przykład skuteczności wieloaspektowego wsparcia. Temat roli i funkcjonowania logopedy w placówkach oświatowych poruszyła w swoim rozdziale Marlena Kurowska. Rozdział autorstwa Agnieszki Borowiec ukazuje natomiast zasady współpracy logopedy z innymi specjalistami: ortodontą i fizjoterapeutą, a ukazany przykład pacjentki z zaburzeniem zgryzu i dysfunkcją połykania potwierdza słuszność działań interdyscyplinarnych. Taki sam model pracy, lecz w placówce służby zdrowia, popiera w swoim opracowaniu Justyna 
Żulewska, przedstawiając studium przypadku 66-letniego pacjenta z afazją globalną. Rozdział ten zamyka recenzowaną monografię.

Istotną wartością książki Metody terapii logopedycznej pod redakcją Anety Domagały i Urszuli Mireckiej jest ukazanie w sposób syntetyczny i uporządkowany wiedzy podawanej już w literaturze logopedycznej, jak również zaprezentowanie metod nowatorskich wraz $\mathrm{z}$ egzemplifikacją ich zastosowania. Należy także podkreślić, że wszystkie rozdziały zostały opracowane na podstawie bogatej literatury przedmiotu $\mathrm{w}$ języku polskim, często poszerzanej o literaturę anglojęzyczną. Przedstawione treści zainteresują osoby pracujące zarówno z dziećmi, młodzieżą, jak i z osobami dorosłymi i w wieku senioralnym.

Monika BudKowsKa

Poradnia Psychologiczno-Pedagogiczna w Radomsku

(D) https://orcid.org/0000-0003-3983-6625 